\title{
SARS-CoV-2: Endoscopy procedures at risk of airborne particles transmission
}

\author{
Frossard $\mathrm{JL}^{1 *}$ and Negro $\mathrm{F}^{1,2}$ \\ ${ }^{1}$ Service of Gastroenterology and Hepatology, Geneva University Hospital, Switzerland \\ ${ }^{2}$ Service of Clinical Pathology, Geneva University Hospital, Switzerland
}

SARS-CoV-2: Endoscopy procedures at risk of airborne particles transmission. SARS-CoV2 is now a pandemic disease and Europe is taking the deadliest toll associated with COVID-19. One of the pivotal issues raised by this outbreak is the diverse routes of viral transmission [1]. Indeed, a better awareness of these crucial data could alter the spreading of the disease, especially among healthcare professionals that represent about $10 \%$ of all patients [2]. Conventional routes of transmission of SARS-CoV-2, i.e. small, virus-laden air droplets and direct contact have been proposed as major routes of contamination. Furthermore, identification of SARS-CoV2 in gastric and intestine tissue [3], stools and toilet facility swabs of units where COVID-19 patients were hospitalized [4] suggest that fecal shedding of SARS$\mathrm{CoV} 2$ occurs and may lead to oro-fecal transmission, as suggested for the SARS-CoV1. The more recent data about aerosol and surface stability of SARS-CoV-2 is to the end of capital significance because it provides a cautionary warning that this virus may be shed through unsuspected routes from the very beginning of the pandemia [5]. The recent analysis of turbulent gas clouds provoked by exhalation has clearly identified their ability to travel great distances [6], a feature that needs full attention because one can underappreciate potential COVID-19 exposure for many health care workers. During endoscopy, routes of SARS-CoV-2 transmission may include person-to-person, respiratory droplets, airborne particles transmission generated during oesophageal intubation, and contact with body fluids or contaminated surfaces in the operating room. More specifically, coughing and retching frequently occur during upper gastrointestinal endoscopy and can therefore generate large volume of aerosols whereas patients that undergo colonoscopy may pass flatus, a characteristic that has been reported to contribute to bacteria dissemination in the immediate vicinity but without viral aerosols route so far.

Health care workers including physiotherapists, intensive care doctors, pneumologists, as well as gastroenterologists should definitively wear appropriate personal protection equipment as stated by Livingston et al. [7] (simple or double gloves, face masks, air-purifying respirators, goggles, face shields, respirators, and gowns). Moreover, dressing, and undressing code modalities should be standardized in every hospital. All data taken together; respirator devices designed to achieve efficient filtration of airborne particles (up to 0.6 microns) should be strongly considered for the above-mentioned healthcare workers to avoid their own contamination (Table 1).

Copyright: (C2020 Frossard JL. This is an open-access article distributed under the terms of the Creative Commons Attribution License, which permits unrestricted use, distribution, and reproduction in any medium, provided the original author and source are credited.
Table 1. Respirator Masks Characteristics. Dust masks filter are classified as either FFP1 (Filtering Face Piece), FFP2, or FFP3, which indicates what and how many particles of suspended dust, mist, or fibers are filtered. All these masks filter particles that measure up to 0.6 microns in size. The total leakage of these face masks is expressed in percentage. FFP2 and FFP3 afford the highest protection against aerosols. Modified and adapted from World Health Organization (https://www.who.int/emergencies/diseases/novel-coronavirus-2019/ advice-for-public/when-and-how-to-use-masks) and recommandations of the French Institut National de Recherche et Sécurité (https://www.esst-inrs.fr/3rb/ressources/ed105.pdf)

\begin{tabular}{|c|c|c|c|}
\hline $\begin{array}{c}\text { Parcticle } \\
\text { Filtartion (\%) }\end{array}$ & $\sim 80$ & $\sim 94$ & FFP1 \\
\hline $\begin{array}{c}\text { Total Leakage } \\
(\%)\end{array}$ & $\sim 22$ & $8-11$ & $2-5$ \\
\hline Main Use & $\begin{array}{c}\text { Food } \\
\text { Industry } \\
\text { Building } \\
\text { Industry }\end{array}$ & Hospital disease control & Hospital disease control \\
\hline Protection & Dust & $\begin{array}{c}\text { Firm and fluid harmful kinds } \\
\text { of dust, smoke and aerosols }\end{array}$ & $\begin{array}{c}\text { Poisonous and volatile } \\
\text { kinds of dust and aerosols }\end{array}$ \\
\hline Color Code & Yellow & White or blue & Red \\
\hline
\end{tabular}

In conclusion, there is accumulating and substantial evidence that the digestive tract is a target of SARS-COV2 virus. Furthermore, data also suggest that airborne particles transmission is a very likely transmission route during endoscopy.

\section{References}

1. Guan W, Ni Z, Hu Y (2020) Clinical characteristics of coronavirus disease 2019 in China. N Engl J Med.

2. https://www.iss.it/comunicati-stampa1/-/asset_publisher/Cz8X9Kas2PGp/content/ id/5292020?

3. Xiao F, Tang M, Zheng X, Liu Y, Li X, et al. (2020) Evidence for gastrointestinal infection of SARS-CoV-2. Gastroenterology 2020.

4. Ong S, YK T, Chia P, Tek Ng O, Wong M, et al. (2020) Air, surface environmental and personal protective equipment contamination by severe acute respiratory syndrome coronarvirus 2 (SARS-CoV-2) from a symptomatic patient. JAMA 323: 1610-1612. [Crossref]

5. Holbrook M (2020) Aerosol and surface stability of SARS-Cov-2 as compared with SARS-CoV1. $N$ Engl J Med.

6. Bourouiba L (2020) Turbulent gas clouds and respiratory pathogen emissions potential implications for reducing transmission of COVID-19. JAMA.

7. Livingston E, Desai A, Berkwits M (2020) Sourcing personal protective equipment during the COVID-19 pandemic. JAMA. [Crossref]

${ }^{\star}$ Correspondence to: Jean-Louis Frossard, MD, Professor of Medicine, Head Service of Gastroenterology and Hepatology, Geneva University Hospital, Rue Gabrielle-Perret-Gentil 41211 Genève, Switzerland, E-mail: jean-louis. frossard@hcuge.ch

Received: June 21, 2020; Accepted: June 26, 2020; Published: June 30, 2020 